\title{
Kekuatan Mengikat Akta Notariil Perjanjian Perkawinan Terkait Harta Bersama yang Dibuat Pasca Pencatatan Perkawinan
}

\author{
Oleh: \\ Natalia Ningsih*, I Made Arya Utama**, I Made Sarjana*** \\ Program Magister Kenotariatan Universitas Udayana \\ e-mail: natalianingsih41@yahoo.com
}

\author{
ABSTRAK \\ KEKUATAN MENGIKAT AKTA NOTARIIL PERJANJIAN PERKAWINAN TERKAIT \\ HARTA BERSAMA YANG DIBUAT PASCA PENCATATAN PERKAWINAN
}

Dalam mengatasi masalah harta kekayaan dari suami isteri yang telah melangsungkan perkawinan, dapat dilakukan melalui perjanjian perkawinan pasca pencatatan perkawinan dengan bentuk penetapan pengadilan negeri. Oleh karena itu jika ada suami isteri belum membuat perjanjian perkawinan yang keduanya bekerja dimana tempat kerjanya mempunyai resiko tinggi akan habisnya harta kekayaan yang diperoleh maka demi masa depan kehidupan suami isteri tersebut dan pendidikan anak-anaknya diperlukan suatu perjanjian perkawinan. Metode pendekatan yang digunakan dalam penelitian ini adalah normatif yang selanjutnya data dianalisis secara normatif kualitatif.Data yang dipergunakan adalah data sekunder yaitu data yang berupa studi kepustakaan dan penetapan pengadilan negeri.

Penelitian ini bertujuan untuk mengetahui tentang bagaimana kekuatan akta notariil perjanjian perkawinan yang dibuat pasca pencatatan perkawinan apabila yang menjadi dasar adalah penetapan dari hakim dan apa dasar pertimbangan hakim memutus permohonan penetapan tersebut dan akibat hukumnya terhadap pihak ketiga setelah adanya penetapan pengadilan negeri.Dari hasil penelitian ini disimpulkan, bahwa dasar dan pertimbangan hakim mengabulkan permohonan pembuatan perjanjian perkawinan pasca pencatatan perkawinan adalah adanya persetujuan kedua belah pihak dari suami isteri, adanya kealpaan dan ketidaktahuan mereka tentang ketentuan pembuatan perjanjian perkawinan yang harus dibuat sebelum atau pada saat perkawinan dilangsungkan dan adanya yurisprudensi dari penetapan hakim sebelumnya. Akibat hukum pembuatan perjanjian perkawinan pasca pencatatan perkawinan yang dibuat secara notariil adalah mengikat kedua belah pihak yaitu suami isteri sehingga terhadap kedudukan harta suami isteri akibat hukumnya menjadi terpisah satu dengan yang lainnya, sedangkan untuk pihak ketiga, mempunyai kekuatan yang mengikat, sepanjang penetapan tersebut pihak ketiga tidak merasa dirugikan.

Kata Kunci: Perjanjian Perkawinan, Pasca Pencatatan

* Mahasiswa Program studi Magister Kenotariatan T.A. 2015/2016

**Pembimbing I

*** Pembimbing II

\section{ABSTRACT}

In addressing the issue of wealth of the husband and wife who have to mate, can be done through post-registration of marriage the marriage covenant with the form of the establishment of the district court. Therefore, if there is a husband and wife have not made a marriage settlement which both work in which the workplace has a high risk of endless treasures acquired for the sake of the future of the conjugal life and the education of his children needed a covenant marriage. The method used in this study is further normative normative data is analyzed qualitatively. The data used is secondary data is data in the form of literary study and determination of the district court.

This study aims to find out about how the power of notary deed covenant marriage made after the registration of marriage if the basis is the determination of the judges and what are the considerations the judge decide upon such determination and its legal consequences towards third parties after the government imposed a state court. From the results of this study concluded that the basis and reasoning judge granted the request of making the marriage covenant after the registration of 
marriage is the consent of both sides of husband and wife, their negligence and ignorance about the provisions of the agreement is a marriage to be made before or at the time the marriage took place and their jurisprudence of the determination of the previous judge. The legal consequences of making the marriage covenant postregistration of marriage shall be notarized is binding on both parties that the marriage so that the standing property conjugal legal effects to be separated from one another, while a third party, has no binding force, as long as the determination of the third party do not feel disadvantaged.

Keywords: Marital Agreements, Post-Recording

* Mahasiswa Program studi Magister Kenotariatan T.A. 2015/2016

**Pembimbing I

*** Pembimbing II

\section{PENDAHULUAN}

\subsection{Latar Belakang}

Secara formil, perjanjian perkawinan adalah suatu perjanjian yang dibuat oleh suami atau isteri untuk mengatur akibat-akibat perkawinannya terhadap harta kekayaan mereka. Perkawinan yang sah menurut hukum akan menimbulkan akibat hukum sebagai berikut: ${ }^{1}$

1. Timbulnya hubungan antara suami isteri;

2. Timbulnya harta benda dalam perkawinan;

3. Timbulnya hubungan antara orang tua dan anak.

Maksud dan tujuan suami isteri membuat janji-janji perkawinan adalah untuk mengatur akibat hukum dari perkawinan yaitu mengenai harta kekayaan agar tidak terjadi persatuan bulat harta kekayaan perkawinan diantara suami isteri selama perkawinan. Dalam UU Perkawinan, pembuatan perjanjian perkawinan diatur dalam Pasal 29 ayat (1), (2), (3) dan (4) sebagai berikut:

(1) Pada waktu atau sebelum perkawinan dilangsungkan, kedua pihak atas persetujuan bersama dapat mengadakan perjanjian tertulis yang disahkan oleh pegawai pencatat perkawinan, setelah mana isinya berlaku juga terhadap pihak ketiga sepanjang pihak ketiga tersangkut;

(2) Perjanjian tersebut tidak dapat disahkan bilamana melanggar batas-batas hukum, agama dan kesusilaan;

(3) Perjanjian tersebut mulai berlaku sejak perkawinan dilangsungkan;

(4) Selama perkawinan berlangsung perjanjian tersebut tidak dapat dirubah kecuali bila dari kedua belah pihak ada persetujuan untuk merubah dan perubahan tidak merugikan pihak ketiga.Berdasarkan rumusan di atas

${ }^{1}$ Mulyadi, 2008, Hukum Perkawinan Indonesia, Cetakan Pertama, Semarang: Badan Penerbit Universitas Diponegoro, hal. 41. terdapat 5 (lima) unsur yang menjadi dasar hukum dari perjanjian perkawinan yaitu:

a. Perjanjian perkawinan harus dibuat sebelum atau pada saat perkawinan dilangsungkan. Hal ini menunjukkan perumusan yang lebih luas dan longgar mengenai adanya dua macam waktu untuk membuat perjanjian perkawinan bagi calon pasangan suami isteri, yaitu "sebelum dan pada saat perkawinan dilangsungkan" sehingga "tidak diperbolehkan membuat perjanjian perkawinan setelah perkawinan berlangsung". Makna yang terkandung dalam kata "sebelum" adalah bahwa perjanjian perkawinan itu dibuat sebelum perkawinan itu dilakukan menurut hukum agama dan kepercayaan dari calon suami isteri sesuai dengan sahnya perkawinan menurut Pasal 2 ayat (1) dan ayat (2) UU Perkawinan. Sedangkan makna kata "pada saat perkawinan dilangsungkan" adalah perjanjian perkawinan itu dibuat pada saat perkawinan berlangsung yaitu saat sahnya perkawinan menurut hukum agama dan kepercayaan dari calon suami isteri dan setelah itu langsung dilakukan pencatatan dihadapan pegawai pencatat perkawinan.

b. Bentuk perjanjian perkawinan dapat dibuat dalam bentuk tertulis.

Pernyataan kata "dapat" menimbulkan penafsiranbahwa perjanjian perkawinanitu dapat dibuat secara notariil, dibawah tangan atau bahkan secara diam-diam.

c. Perjanjian perkawinan yang dibuat harus disahkan atau dicatatkan oleh pegawai pencatat perkawinan.

d. Perjanjian perkawinan isinya tidak boleh melanggar batas-batas hukum, agama dan kesusilaan.

e. Perjanjian perkawinan pada prinsipnya tidak boleh dirubah maksudnya adalah kecuali apabila suami isteri menyetujui untuk merubah perjanjian perkawinan dan perubahan tersebut tidak merugikan pihak ketiga, maka berdasarkan UU Perkawinan perubahan tersebut dimungkinkan.

Perjanjian perkawinan mulai berlaku sejak saat perkawinan 
dilangsungkan, sedangkan bagi pihak ketiga, perjanjian perkawinan baru berlaku setelah dibukukan atau didaftarkan di dalam suatu register umum.Meskipun dalam Pasal 29 ayat (2) UU Perkawinan tidak secara tegas menyebutkan mengenai isi perjanjian perkawinan tetapi melihat ketentuan Pasal 1338 KUH Perdata, dapat diartikan bahwa isi tentang perjanjian perkawinan tersebut dapat meliputi apa saja sepanjang tidak bertentangan dengan hukum agama dan kesusilaan. Kalau sesuai dengan makna yang ada pada perjanjian perkawinan itu sendiri maka dalam hal ini perjanjian perkawinan meliputi harta kekayaan calon suami isteri yakni berupa:

1. Harta bersama yang didapat calon suami isteri selama perkawinan

2. Harta bawaan masing-masing calon suami isteri sebelum perkawinan

Dalam UU Perkawinan, mengenai harta benda dalam perkawinan, pengaturannya dapat dilihat dalam Pasal 35, 36, dan 37 yang menyatakan sebagai berikut :

Pasal 35:

(1) Harta benda yang diperoleh selama perkawinan menjadi harta bersama.

(2) Harta bawaan dari masing-masing suami dan isteri dan harta benda yang diperoleh masingmasing sebagai hadiah atau warisan, adalah dibawah penguasaan masing-masing sepanjang para pihak tidak menentukan lain.

Pasal 36:

(1) Mengenai harta bersama, suami atau isteri dapat bertindak atas persetujuan kedua belah pihak.

(2) Mengenai harta bawaan masing-masing, suami dan isteri mempunyai hak sepenuhnya untuk melakukan perbuatan hukum mengenai harta bendanya.

Pasal 37:

Bila perkawinan putus karena perceraian, harta bersama diatur menurut hukumnya masingmasing.

Pasal 36 ayat (1) UU Perkawinan tersebut mencerminkan suatu kedudukan yang setara terhadap kekuasaan atas harta bersama dalam perkawinan. Kedudukan yang setara di atas melahirkan tanggung jawab dari suami dan isteri tersebut manakala secara bersama-sama atau salah satu melakukan suatu perbuatan hukum terhadap harta bersama tersebut atau salah satu dari mereka melakukan suatu perbuatan hukum perkawinan. ${ }^{2}$ Pasal 29 ayat (1) UU Perkawinan telah menegaskan bahwa pada waktu atau sebelum perkawinan

${ }^{2}$ Sonny Dewi Juniasih,2015, Harta Benda Perkawinan (Kajian Terhadap Kesetaraan Hak dan Kedudukan Suami dan Isteri atas Kepemilikan Harta dalam Perkawinan), Bandung: PT. Refika Aditama, hal. 25. dilangsungkan, kedua pihak atas persetujuan bersama dapat mengadakan perjanjian tertulis yang disahkan oleh pegawai pencatat perkawinan, setelah mana isinya berlaku juga terhadap pihak ketiga sepanjang pihak ketiga tersangkut. Jika berpegang pada ketentuan pasal 29 ayat (1) sudah jelas dikatakan bahwa perjanjian perkawinan itu dibuat "sebelum perkawinan dilangsungkan".

Tetapi pada makna kata "pada saat perkawinan dilangsungkan" akan menimbulkan 2 (dua) penafsiran yang berbeda dimana disatu pihak bisa ditafsirkan pada saat perkawinan itu dilangsungkan adalah pada saat perkawinan itu sedang diupacarai secara keagamaan ataukah perkawinan itu sedang berlangsung sebelum terjadi perceraian diantara pasangan suami isteri tersebut. Terkait penafsiran yang berbeda di atas dan seiring dengan perkembangan zaman saat ini, sudah ada keluar penetapan hakim dari Pengadilan Negeri Tangerang Nomor: 269/PEN.PDT.P/2015/PN.Tng. mengenai perjanjian perkawinan yang dibuat pasca pencatatan perkawinan yang diajukan oleh pasangan suami isteri dalam perkawinan campuran yang berbeda kewarganegaraan dimana suaminya berkewarganegaraan Jerman dan isterinya berkewarganegaraan Indonesia yang telah menikah selama 17 (tujuh belas) tahun.

Bertitik tolak dari uraian tersebut di atas yang berawal dari adanya perjanjian perkawinan yang dibuat berdasarkan penetapan pengadilan negeri, maka penulis tertarik untukmelakukan penelitian mengenai "Kekuatan Mengikat Akta Notariil Perjanjian Perkawinan Terkait Harta Bersama Pasca Pencatatan Perkawinan". Hal ini tentu saja menimbulkan suatu penafsiran yang berbeda dari dasar hukum perjanjian perkawinan yang terdapat dalam Pasal 29 ayat (1) Undang-Undang Nomor 1 Tahun 1974 tentang Perkawinan, sehingga menimbulkan adanya norma yang kabur pada pasal tersebut di atas.

\subsection{Rumusan Masalah}

1. Apakah yang menjadi ruang lingkup substansi dari pembuatan akta notariil perjanjian perkawinan pasca pencatatan perkawinan terkait pengaturan harta bersama?

2. Bagaimanakah kekuatan mengikat akta notariil perjanjian perkawinan mengenai harta bersama yang dibuat pasca pencatatan perkawinan terhadap pihak ketiga yang terkait?

\subsection{Tujuan Penelitian \\ 1.3.1. Tujuan Umum}

Secara umum yang menjadi tujuan penelitian ini adalah untuk mengkaji dan menganalisa, "Kekuatan Mengikat Akta Notariil Perjanjian Perkawinan 
Terkait Harta Bersama yang Dibuat Pasca Pencatatan Perkawinan".

\subsubsection{Tujuan Khusus}

a. Untuk mengetahui dan menganalisis mengenai apa yang menjadi ruang lingkup substansi dari pembuatan akta notariil perjanjian perkawinan terkait harta bersama yang dibuat pasca pencatatan perkawinan.

b. Untuk mengetahui dan menganalisis mengenai kekuatan mengikat akta notariil perjanjian perkawinan terkait harta bersama yang dibuat pasca pencatatan perkawinan terhadap pihak ketiga yang terkait.

\subsection{Manfaat Penelitian}

\subsubsection{Manfaat Teoritis}

Manfaat teoritis dari penelitian ini diharapkan dapat dijadikan referensi, tambahan ilmu dan memperdalam perkembangan hukum perkawinan yang berkaitan dengan perjanjian perkawinan terkait harta bersama yang dibuat pasca pencatatan perkawinan.

\subsubsection{Manfaat Praktis}

Manfaat praktis dari penelitian ini diharapkan mampu memberikan masukan, manfaat dan menambah informasi bagi akademisi, Notaris dan pemerintah mengenai kekuatan mengikat perjanjian perkawinan yang dibuat pasca pencatatan perkawinan.

\subsection{Landasan Teoritis dan Konsep}

\subsubsection{Landasan Teoritis}

\subsubsection{Teori Hukum Progresif}

Menurut Teori Hukum Progresif sebagaimana yang dicetuskan oleh Satjipto Rahardjo, bahwa hukum adalah untuk manusia, dan bukan sebaliknya. "Hukum itu bukan hanya bangunan peraturan, melainkan juga bangunan ide, kultur, dan cita-cita". ${ }^{3}$ Beliau menyatakan pemikiran hukum perlu kembali pada filosofis dasarnya, yaitu hukum bertugas melayani manusia, sehingga manusia menjadi penentu dan titik orientasi hukum. Oleh karena itu, hukum itu bukan merupakan institusi yang lepas dari kepentingan manusia.

Mutu hukum ditentukan oleh kemampuannya untuk mengabdi pada kesejahteraan manusia. Untuk itu agar hukum dirasakan manfaatnya, maka dibutuhkan jasa pelaku hukum yang kreatif menterjemahkan hukum itu dalam kepentingan-kepentingan sosial yang memang harus dilayaninya.

Berdasarkan teori ini keadilan tidak bisa secara langsung ditemukan lewat proses logis formal. Keadilan justru diperoleh lewat institusi, karenanya, argumen-argumen logis formal "dicari" pasca keadilan ditemukan untuk membingkai secara yuridis-formal

${ }^{3}$ Satjipto Rahardjo, 2006, Ilmu Hukum, Bandung: PT. Citra Aditya Bakti, hal. 32. keputusan yang diyakini adil tersebut. Oleh karena itu konsep hukum progresif, hukum tidak mengabdi bagi dirinya sendiri, melainkan untuk tujuan yang berada di luar dirinya.

\subsubsection{Teori Kepastian Hukum}

Menurut W.J.S Poerwadarminta, "kepastian" berasal dari kata "pasti" yang artinya tentu, sudah tetap, tidak boleh tidak, suatu hal yang sudah tentu. ${ }^{4}$ Kepastian hukum adalah pertanyaan yang hanya bisa dijawab secara normatif dan tidak bisa dijawab secara sosiologis. Kepastian hukum secara normatif adalah ketika suatu peraturan dibuat dan diundangkan secara pasti karena mengatur secara jelas dan logis, dan jelas dalam artian tidak menimbulkan tafsir yang berbeda dan logis dalam artian dapat menjadi sistem norma dengan norma lain sehingga tidak berbenturan atau menimbulkan konflik norma.

Kepastian hukum berarti hukum harus memberikan kejelasan atas tindakan pemerintah dan masyarakat, sehingga memberikan kepastian hukum dan tidak menimbulkan multitafsir atas aturan hukum tersebut. Selain itu, aturan hukum satu dengan aturan hukum lainnya haruslah terjalin suatu harmonisasi sehingga aturan tersebut tidak kontradiktif atau berlawanan antara satu dengan aturan lainnya.

\subsubsection{Teori Nilai Dasar Hukum}

Menurut Gustav Radbruch sebagai pencetus teori nilai dasar hukum mengatakan, "Nilai-nilai dasar dari hukum ada tiga (3) yaitu: kepastian hukum, keadilan, dan kemanfaatan." Menurutnya juga, "Karena dalam nilai-nilai dasar dari hukum terdapat suatu Spannungsverhaltnis, suatu ketegangan satu sama lain dan masalah ini biasanya dibicarakan dalam hubungan dengan berlakunya hukum." $" 6$

Sebagai contohnya tentang nilai dasar kepastian hukum, maka sebagai nilai ia akan menggeser nilai-nilai keadilan dan kegunaan ke samping (manfaat). Yang utama dari nilai kepastian hukum adalah adanya peraturan itu sendiri. "Tentang apakah peraturan itu harus adil dan mempunyai kegunaan bagi masyarakat, adalah di luar pengutamaan nilai kepastian hukum."

${ }^{4}$ W.J.S.Poerwadarminta, 2006, Kamus Umum Bahasa Indonesia, Edisi Ketiga, Jakarta: Balai Pustaka, hal. 84.

${ }^{5}$ Satjipto Rahardjo, op.cit., hal. 19.

${ }^{6}$ Satjipto Rahardjo, loc.cit.

${ }^{7}$ Satjipto Rahardjo, loc.cit. 


\subsubsection{Teori Perlindungan Hukum}

Menurut Van Apeldoorn ${ }^{8}$ tujuan hukum adalah untuk mengatur pergaulan hidup secara damai. Hukum menginginkan kedamaian diantara manusia dengan melindungi kepentingankepentingan manusia yang tertentu, yaitu kehormatan, kemerdekaan, jiwa, harta benda dan sebagainya. Fitzgerald mengemukakan hukum bertujuan mengintegrasikan dan mengkoordinasikan berbagai kepentingan dalam masyarakat karena suatu lalu lintas kepentingan, perlindungan terhadap kepentingan tertentu hanya dapat dilakukan dengan cara membatasi berbagai kepentingan dilain pihak. ${ }^{9}$ Kepentingan hukum adalah mengurusi hak dan kepentingan manusia, sehingga hukum memiliki otoritas tertinggi untuk menentukan kepentingan manusia yang perlu diatur dan dilindungi. ${ }^{10}$

\subsubsection{Konsep}

a. Kekuatan Mengikat Akta Notariil

Maksudnya adalah bagaimana berlakunya perjanjian perkawinan yang dibuat pasca pencatatan perkawinan yang dibuat dalam bentuk akta notariil apabila dikaitkan dengan keluarnya Putusan Hakim Pengadilan Negeri Tangerang Nomor:269/PEN.PDT.P/2015/PN.Tng.

Akta Notariil adalah akta yang dibuat dan dibacakan serta ditandatangani di depan Notaris.Isi akta merupakan keinginan para pihak tapi sebagai pejabat umum, Notaris bertanggung jawab penuh atas isi akta tersebut mengenai kebenaran dan ketentuan-ketentuan yang ada di dalamnya, menjamin tanggalnya dan orang atau para pihak yang menandatangani akta tersebut adalah orang yang cakap berwenang.

b. Perjanjian Perkawinan

Perjanjian perkawinan adalah suatu perjanjian perkawinan yang dibuat oleh suami isteri selama perkawinan berlangsungkan mengenai segala harta yang berhubungan dengan kekayaan dari suami isteri tersebut.

c. Harta Benda Perkawinan

Harta benda perkawinan dalam perjanjian perkawinanmenurut UU Perkawinan dibagi atas 2 (dua) jenis yaitu:

1) Harta bersama suami isteri adalah harta yang didapat dan diperoleh suami isteri selama perkawinan mereka berlangsung;

2) Harta bawaan suami isteri adalah harta yang dibawa masing-masing pasangan suami isteri sebelum perkawinan mereka dilangsungkan.

d. Perjanjian Perkawinan Pasca Pencatatan Perkawinan

${ }^{8}$ L.J van Apeldoorn, 2004, Pengantar Ilmu

Hukum, Jakarta: Pradnya Paramita, hal. 10.

${ }^{9}$ Satjipto Rahardjo, op.cit., hal. 53.

${ }^{10}$ Satjipto Rahardjo, op.cit., hal. 69.
Perjanjian perkawinan pasca pencatatan adalah perjanjian perkawinan yang dibuat setelah perkawinan dilakukan secara hukum agama dan kepercayaan masing-masing suami isteri sesuai dengan bunyi Pasal 2 ayat (1) UU Perkawinan, kemudian setelah itu dilakukan pencatatan perkawinan tersebut pada kantor pencatatan perkawinan setempat sesuai Pasal 2 ayat (2) UU Perkawinan.

e. Penetapan Hakim

Penetapan hakim adalah keputusan pengadilan atas perkara permohonan dan tidak ada lawan hukum.

\subsection{METODE PENELITIAN \\ 1.6.1. Jenis penelitian}

Jenis Penelitian yang digunakan dalam penelitian tesis ini adalah penelitian hukum normatif, berangkat dari adanya kekaburan norma pada Pasal 29 ayat (1) UU Perkawinan.

\subsubsection{Jenis Pendekatan}

Pendekatan yang digunakan dalam penulisan ini adalah pendekatan peraturan perundang-undangan (the Statute Approach) dan pendekatan Analisis Konsep Hukum (Analitical and Conseptual Approach).

\subsubsection{Sumber Bahan Hukum}

Sumber bahan hukum yang digunakan dalam penelitian ini meliputi:

1. Bahan hukum primer, yaitu bahan hukum yang mempunyai kekuatan mengikat, berupa peraturan perundang-undangan, yaitu berupa Undang-Undang nomor 1 tahun 1974 tentang Perkawinan, Kitab Undang-Undang hukum Perdata, Undang-Undang Nomor 23 Tahun 2006 tentang Administrasi Kependudukan, Undang-Undang Nomor 5 tahun 1960 Tentang Undang-Undang pokok Agraria, Undang-Undang Nomor 40 Tahun 2007 tentang Perseroan Terbatas, Undang-Undang Nomor 2 Tahun 2014 tentang Perubahan Atas Undang-Undang Nomor 30 Tahun 2004 tentang Jabatan Notaris, Peraturan Pemerintah Nomor 9 Tahun 1975 tentang Pelaksanaan Undang-Undang Nomor 1 Tahun 1974 tentang Perkawinan dan yurisprudensi hakim.

2. Bahan hukum sekunder, yaitu bahan hukum sekunder yang digunakan adalah buku literatur dibidang hukum perdata, hukum perkawinan, hukum perjanjian, dan lainnya yang terkait.

3. Bahan hukum tersier, yaitu bahan hukum yang dapat memberikan penjelasan terhadap bahan hukum primer maupun bahan hukum sekunder yang berupa kamus hukum, ensiklopedia, dan kamus besar bahasa Indonesia. 


\subsection{Teknik Pengumpulan Bahan Hukum}

Teknik pengumpulan bahan hukum dalam penelitian ini adalah dengan melakukan studi kepustakaan menggunakan sistem kartu (card system) untuk mencatat hal-hal penting yang merupakan bahan hukum yang relevan dengan permasalahan yang dibahas.

\subsection{Teknik Analisis Bahan Hukum}

Teknik pengolahan dan analisis bahan hukum yang digunakan dalam penelitian ini diawali dengan mengumpulkan bahan-bahan hukum secara sistematis yang kemudian dianalisis guna mengetahui secara rinci permasalahan yang dihadapi dalam penelitian ini dengan menggambarkan apa adanya terhadap suatu masalah (deskripsi) dan kemudian menjelaskan permasalahan yang ada (eksplanasi), lalu mengkaji permasalahan dengan mengkonstruksi ketentuan hukum sehingga didapatkan ketentuan norma yang mampu menyelesaikan permasalahan yang dikaji dalam penelitian ini.

\section{B AB II \\ TINJAUAN UMUM TENTANG PERKAWINAN, PERJANJIAN PERKAWINAN, DAN PENCATATAN PERKAWINAN}

\subsection{Perkawinan}

\subsubsection{Pengertian Perkawinan}

Definisi perkawinan menurut Pasal 1 UU Perkawinan adalah ikatan lahir batin antara seorang pria dengan seorang wanita sebagai suami isteri untuk membentuk rumah tangga (keluarga) yang bahagia dan kekal berdasarkan Ketuhanan Yang Maha Esa". Penjelasan Pasal 1 UU Perkawinan menjelaskan bahwa, "Sebagai Negara yang berdasarkan Pancasila, dimana sila yang pertamanya yang berbunyi, "Ketuhanan Yang Maha Esa", maka perkawinan mempunyai hubungan yang erat sekali dengan agama/kerohanian, sehingga perkawinan bukan saja mempunyai unsur lahir/jasmani tetapi unsur batin/rohani juga mempunyai peranan yang sangat penting.

Sedangkan pengertian perkawinan menurut hukum adat bersangkutan dengan perikatan perdata dan perikatan kekerabatan. Menurut Ter Haar, perkawinan merupakan "urusan kerabat,urusan keluarga, urusan masyarakat, urusan martabat dan urusan pribadi."11 Pendapat lain tentang pengertian perkawinan juga dikemukakan oleh Sajuti Tahlib, menurutnya perkawinan adalah "Perjanjian suci membentuk keluarga antara seorang laki-laki dengan seorang perempuan." 12

Beberapa pengertian perkawinan di atas jika dibandingkan dengan pengertian perkawinan berdasarkan Pasal 1 UU Perkawinan, tidak terdapat perbedaan yang prinsip. Berlakunya UU Perkawinan menyebabkan perkawinan tidak boleh dipandang dari sudut hubungan keperdataan saja, tetapi perkawinan harus dipandang pula dari unsur biologis, unsur sosiologis dan unsur religius.

\subsubsection{Perkawinan Campuran}

Pengertian perkawinan campuran menurut Pasal 57 UU Perkawinan adalah perkawinan antara dua orang yang di Indonesia tunduk pada hukum yang berlainan, karena perbedaan kewarganegaraan dan salah satu pihak berkewarganegaraan Indonesia

\subsubsection{Syarat Sahnya Perkawinan}

Menurut UU Perkawinan, syarat sahnya perkawinan di bedakan atas 2 (dua) syarat, yaitu:

1. Syarat-syarat Materiil yaitu syarat yang harus dipenuhi mengenai diri pribadi dari seseorang yang hendak melangsungkan perkawinan dan izin-izin yang harusdiberikan oleh pihak ketiga dalam hal ditentukan oleh undangundang. Syarat materiil ini terbagi menjadi 2 (dua), yaitu:

a. Syarat Material Umum atau disebut juga Syarat Materiil Absolute, adalah syarat yang mutlak dan harus dipenuhi oleh siapapun yang hendak kawin, apabila tidak dipenuhi dapat menyebabkan calon suami isteri tersebut tidak dapat melangsungkan perkawinan, ${ }^{13}$ diantaranya :

1) Adanya persetujuan kedua calon suami isteri.

2) Syarat usia menurutPasal 7 ayat (1) UU bagi laki-laki berumur 19 tahun dan wanita berumur 16 tahun.

3) Tidak pernah kawinsesuai Pasal 9 UU Perkawinan.

4) Berlakunya Tenggang Waktu Tunggu Bagi Wanitayang putus

${ }^{11}$ Ter Haar, 1960, Asas-asas dan Susunan Hukum Adat (terjemahan Soebakti Poesponoto K. Ng.), Jakarta: Pradnya Paramita, hal. 158.

${ }^{12}$ Sajuti Thalib, 1974, Hukum Kekeluargaan Indonesia, Jakarta: Yayasan Penerbit Universitas Indonesia, hal. 47.

${ }^{13}$ R. Abdoel Djamali, 2003, Pengantar Hukum Indonesia, Cetakan ke-8, Jakarta: Raja Grafindo, hal. 22. 
perkawinan sesuai Pasal 11 UU Perkawinan.

b. Syarat Materiil Khusus/Relatif, adalah syarat yang menyangkut pribadi suami isteriyang dikawiniberkenaan dengan larangan dan ijin perkawinan.

2. Syarat formil perkawinan adalah syarat yang berkaitan dengan tata cara pelangsungan perkawinan yang meliputi syarat yang mendahului pelangsungan perkawinan dan syarat yang menyertai pelangsungan perkawinan sebagaimana yang diaturdi dalam Pasal 12 UU Perkawinan ${ }^{14}$ diantaranya :

1. Pemberitahuan tentang akan dilangsungkannya perkawinan dengan cara pendaftaran kepada pegawai catatan sipil;

2. Penelitian dan pengecekan terhadap pemenuhan syarat-syarat perkawinan yang didaftarkan;

3. Pencatatan dalam daftar yang diperuntukkan untuk itu;

4. Pengumuman tentang pemberitahuan dilangsungkannya perkawinan;

\subsubsection{Tata Cara Perkawinan}

Diatur dalam Pasal 8 dan Pasal 10 PP No.9/1975 yang menyebutkan bahwa perkawinan dilangsungkan setelah hari kesepuluh sejak pengumuman kehendak perkawinan oleh pegawai pencatat. Adapun tata cara perkawinan dilakukan menurut hukum, agama dan kepercayaan masingmasing, dihadiri dua orang saksi dan kedua mempelai menandatangai akta perkawinan dihadapan dihadapan pegawai pencatat perkawinan.

\subsubsection{Akibat Perkawinan}

Perkawinan merupakan kesepakatan bersama antara suami dan isteri untuk melakukan hidup bersama, sehingga dari perkawinan itu menimbulkan hak dan kewajiban.

\subsection{Perjanjian Perkawinan}

\subsubsection{Pengertian Perjanjian Perkawinan}

Menurut ketentuan yang terdapat dalam Pasal 29 UU Perkawinan dan KUH Perdata tidak jelas dikatakan dengan apa yang dimaksud dengan perjanjian perkawinan. Terkait dengan pengertian perjanjian perkawinan dapat dilihat dari beberapa pendapat para sarjana.Menurut R. Subakti "Baik KUH Perdata maupun UU Perkawinan mengenal yang dinamakan "perjanjian perkawinan". Ini adalah suatu perjanjian mengenai harta benda suami isteri selama perkawinan mereka yang menyimpang dari asas atau pola yang ditetapkan oleh undang-undang." 15

Selain itu, R. Soetojo Prawirohamidjojo dan Asis Safioedin, berpendapat bahwa perjanjian perkawinan adalah "Perjanjian yang dibuat oleh dua orang suami isteri untuk mengatur akibat-

${ }^{14}$ Ibid. hal. 45.

${ }^{15}$ Subekti, 2000, Pokok-pokok Hukum Perdata, Jakarta: Intermasa, hal. 8-9. akibat perkawinan mengenai harta kekayaan."16 Jika perjanjian perkawinan dilihat dari segi perjanjian, Herlien Budiono menyatakan perjanjian perkawinan merupakan "perjanjian diantara suami isteri dengan tujuan yang berakibat terhadap harta benda dari perkawinan yang akan dilakukan dan untuk sahnya perjanjian tersebut harus memenuhi ketentuan perundang-undangan serta ketentuan mengenai kapan berlakunya terhadap pihak ketiga."17

\subsubsection{Tujuan Perjanjian Perkawinan}

Pada umumnya tujuan perjanjian perkawinan yang dibuat oleh calon suami isteri adalah mengatur mengenai harta perkawinan sebagaimana yang terdapat dalam Pasal 35, 36, dan 37 UU Perkawinan yaitu mengenai harta bawaan, harta bersama, serta pengaturan harta bersama jika terjadi perceraian, dimana harta tersebut diatur menurut hukumnya masingmasing, seperti hukum agama, hukum adat, dan hukum lainnya.

\subsubsection{Tata Cara Perjanjian Perkawinan Sebelum Pencatatan Perkawinan}

Secara formal perjanjian perkawinan diatur dalam Pasal 29 UU Perkawinan yang menentukan bahwa:

1. Pada waktu atau sebelum perkawinan dilangsungkan, kedua pihak atas persetujuan bersama dapat mengadakan perjanjian tertulis yang disahkan oleh pegawai pencatat perkawinan, setelah mana isinya berlaku juga terhadap pihak ketiga sepanjang pihak ketiga tersangkut.

2. Perjanjian tersebut tidak dapat disahkan bilamana melanggar batas-batas hukum, agama dan kesusilaan.

3. Perjanjian tersebut berlaku sejak perkawinan dilangsungkan.

4. Selama perkawinan berlangsung perjanjian tersebut tidak dapat dirubah, kecuali bila dari kedua belah pihak ada persetujuan untuk merubah dan perubahan tidak merugikan pihak ketiga.

Keempat bunyi pasal di atas terlihat adanya 2 (dua) macam waktu untuk membuat perjanjian perkawinan yaitu bahwa perjanjian perkawinan dapat dibuat" sebelum perkawinan dilangsungkan" atau "pada saat perkawinan dilangsungkan." Sehingga saat untuk pembuatan perjanjian perkawinan tersebut telah ditentukan maka "tidak diperbolehkan membuat perjanjian perkawinan setelah perkawinan berlangsung".

Makna yang terkandung dalam kata "sebelum" adalah bahwa perjanjian perkawinan itu dibuat sebelum perkawinan itu dilakukan menurut hukum agama dan kepercayaan dari calon suami isteri sesuai dengan sahnya

${ }^{16}$ R. Soetojo Prawirohamidjojo dan Asis Safioedin, 1986, Hukum Orang dan Keluarga, Bandung: Alumni, hal. 76.

${ }^{17}$ Herlien Budiono, 2010, Kumpulan Tulisan Hukum Perdata di Bidang Kenotariatan Buku Kedua, Bandung: PT. Citra Aditya Bakti, hal. 4. 
perkawinan menurut Pasal 2 ayat (1) yang berbunyi: "Perkawinan adalah sah apabila dilakukan menurut hukum masing-masing agama dan kepercayaannya itu." dan Pasal 2 ayat (2) yang menyebutkan: "Tiap-tiap perkawinan dicatat menurut peraturan perundang-undangan yang berlaku." Sedangkan makna kata "pada saat perkawinan dilangsungkan" adalah perjanjian perkawinan itu dibuat pada saat perkawinan berlangsung yaitu saat sahnya perkawinan menurut hukum agama dan kepercayaan dari calon suami isteri dan setelah itu langsung dilakukan pencatatan dihadapan pegawai pencatat perkawinan menurut ketentuan yang terdapat dalam Pasal 2 ayat (2) UU Perkawinan.

Mengenai prosedur dan tata cara perjanjian perkawinan yang dilakukan sebelum atau pada saat melangsungkan perkawinan sebagaimana yang ditentukan dalam Pasal 2 ayat (1) dan ayat (2) UU Perkawinan hampir sama dengan prosedur pembuatan perjanjian perkawinan yang dilakukan sebelum pencatatan perkawinan. Perjanjian perkawinan yang dilakukan sebelum pencatatan perkawinan maksudnya adalah perjanjian perkawinan yang dilakukan oleh calon suami isteri sebelum atau pada saat perkawinan dilangsungkan sebagaimana yang diatur dalam Pasal 2 ayat (1) UU Perkawinan seperti yang telah disebutkan di atas dan belum dicatatkan sesuai peraturan yang berlaku, jadi belum memenuhi ketentuan yang terdapat dalam Pasal 2 ayat (2) yang menyebutkan: "Pencatatan tiap-tiap perkawinan adalah sama halnya dengan pencatatan peristiwa-peristiwa penting dalam kehidupan seseorang, misalnya kelahiran, kematian."

Adapun tata cara prosedur pembuatan perjanjian perkawinan yang dibuat suami isteri dalam bentuk tertulis dihadapan Notaris sebelum pencatatan perkawinan adalah calon suami isteri yang akan melangsungkan perkawinannya terlebih dahulu datang ke kantor Notaris untuk membuat perjanjian perkawinan dengan membawa kelengkapan Kartu Tanda Penduduk (KTP) dan Kartu Keluarga (KK). Sedangkan bagi pasangan calon suami isteri yang berbeda kewarganegaraan harus membawa paspor atau kitas. Pihak Notaris akan meneliti kelengkapan persyaratan yang dibawa oleh calon suami isteri tersebut dan kemudian dicocokkan dengan aslinya. Apabila sudah benar kelengkapan identitas calon suami isteri maka Notaris akan memanggil calon suami isteri itu untuk menanyakan mengenai isi dari perjanjian perkawinan yang disepakati untuk dicantumkan dalam draft perjanjian perkawinan.

Apabila draft perjanjian perkawinan yang dibuatkan Notaris telah selesai maka draft tersebut terlebih dahulu diberikan kepada calon suami isteri tersebut untuk dibaca dan dipahami maksud setiap kalimat dan pasal dalam akta itu. Apabila telah selesai dibaca dan dipahami maka Notaris akan menanyakan kepada calon suami isteri apakah sudah setuju dengan isi yang terdapat dalam draft yang dibuat Notaris. Kalau draft sudah disetujui maka Notaris akan membacakan akta sesuai hari dan tanggal pada saat itu. Apabila telah selesai dibaca dan tidak ada perubahan lagi maka akta siap ditanda tangani oleh calon suami isteri untuk kemudian dikeluarkan salinan oleh Notaris.

Kemudian salinan akta perjanjian perkawinan yang telah dibuat di Notaris tersebut harus disahkan dihadapan pegawai pencatat perkawinan selambat-lambatnya dalam jangka waktu 60 (enam puluh) hari sebelum perkawinan dilangsungkan atau saat perkawinan berlangsung, yaitu saat perkawinan telah melakukan perkawinan sesuai Pasal 2 ayat (1) UU Perkawinan. Pegawai pencatat perkawinan akan mencatatkan perjanjian perkawinan itu pada pinggir kolom dari akta perkawinan yang telah disediakan untuk itu.

Akibat perjanjian perkawinan yang dilakukan sebelum atau pada saat perkawinan berlangsung apabila akta perjanjian perkawinannya telah disahkan oleh pegawat pencatat perkawinan dan telah pula didaftarkan di kepaniteraan pengadilan negeri, maka perjanjian perkawinan tersebut berlaku bagi suami dan isteri, juga berlaku bagi pihak ketiga. Dalam hal perjanjian perkawinan itu belum didaftarkan ke kepaniteraan pengadilan negeri dan belum tercatat dalam akta perkawinan suami isteri tersebut, maka para pihak ketiga boleh menganggap suami isteri itu melakukan perkawinan dalam percampuran harta kekayaan. Pihak ketiga yang tersangkut dalam perjanjian perkawinan suami isteri adalah pihak lain yang mengadakan hubungan hukum dengan suami isteri, misalnya: hubungan dagang yang mungkin dapat menimbulkan kerugian bagi pihak ketiga atau pihak yang memberikan utang.

Menurut ketentuan Pasal 29 ayat (2) UU Perkawinan disebutkan "Perjanjian perkawinan tidak dapat disahkan bilamana melanggar batasbatas hukum, agama dan kesusilaan." Sebagai contoh hal yang melanggar batas hukum adalah apabila suami isteri membuat perjanjian perkawinan yang berisi bahwa yang satu mempunyai kewajiban lebih besar dalam utangutang daripada bagiannya dalam keuntungan harta bersama sebagaimana tersebut dalam Pasal 142 KUH Perdata. Hal ini tidak boleh diperjanjikan dalam membuat perjanjian perkawinan karena telah melanggar batas-batas hukum sehingga perjanjian perkawinannya tidak dapat disahkan oleh pegawai pencatat perkawinan sebagaimana yang diatur dalam Pasal 29 ayat (1) UU Perkawinan. Dengan demikian sahnya perjanjian perkawinan adalah jika aktanya telah didaftarkan di kepaniteraan pengadilan negeri dan dicatat adanya perjanjian perkawinan tersebut, pada akta perkawinan oleh petugas Kantor Catatan Sipil (selanjutnya disebut KCS). 
Ada beberapa isi perjanjian perkawinan yang dicantumkan dalam akta yang dibuat dihadapan Notaris diantaranya adalah:

1. Perjanjian Perkawinan Pisah Harta

Maksudnya perjanjian perkawinan yang dibuat suami isteri dimana ditentukan dalam perkawinan mereka tidak ada persatuan harta atau dengan kata lain tidak ada harta bersama yang timbul sebagai akibat perkawinan suami isteri.

2. Perjanjian Perkawinan Persatuan Untung dan Rugi

Maksud yang terkandung di dalam perjanjian persatuan untung dan rugi adalah agar masing masing pihak suami dan isteri akan tetap mempertahankan milik mereka, baik berupa harta kekayaan pribadi bawaan maupun berupa hadiah-hadiah yang khusus diperuntukkan kepada masing-masing pihak dan atau hak-hak yang telah diberikan undang-undang, seperti warisan, hibah dan wasiat. Sedangkan semua penghasilan yang diperoleh dari tenaga atau modal selama perkawinan berlangsung menjadi harta bersama. Begitu pula sebaliknya, segala kerugian yang diderita dalam memenuhi kebutuhan hidup berumah tangga sebagai suami isteri menjadi kerugian dan beban bersama.

3. Perjanjian Perkawinan Persatuan Hasil Pendapatan

Perjanjian persatuan hasil pendapatan adalah perjanjian antara calon suami isteri untuk mempersatukan setiap keuntungan (hasil dan pendapatan) saja. Perjanjian ini berarti serupa dengan "perjanjian untung" semata sedangkan segala kerugian tidak diperjanjikan. Dalam hal ini Wirjono Prodjodikoro mengemukakan bahwa, "Isteri hanya bertanggung jawab atas kerugian yang diderita akibat dari perbuatan sendiri."18

Menurut ketentuan yang terdapat dalam Pasal 147 KUH Perdata menyebutkan bahwa perjanjian perkawinan harus dibuat dengan akta notaris, diadakan sebelum perkawinan dan berlaku sejak saat dilakukan perkawinan, dan tidak boleh pada saat lain. Tidak dipenuhinya syarat tersebut diancam kebatalan, yang mengakibatkan bahwa suami dan isteri dianggap telah melangsungkan perkawinan dengan persatuan harta kekayaan secara bulat. Syarat dibuat dengan akta notaris adalah untuk memperoleh kepastian tanggal pembuatan perjanjian perkawinan, karena kalau perjanjian perkawinan dibuat dengan akta dibawah tangan, maka ada kemungkinan bisa diubah isi perjanjian perkawinan dan syaratnya, ini ada kaitannya dengan ketentuan Pasal 149 KUH Perdata tersebut yang menentukan bahwa perjanjian perkawinan, setelah perkawinan berlangsung dengan cara bagaimanapun tidak boleh diubah.
Ketentuan tersebut merupakan penjabaran dari asas yang terdapat dalam KUH Perdata yaitu bahwa selama perkawinan berlangsung termasuk kalau perkawinan tersebut disambung kembali setelah terputus karena perceraian, bentuk harta perkawinan harus tetap tidak berubah. Hal tersebut dimaksudkan demi perlindungan terhadap pihak ketiga (kreditur) supaya tidak dihadapkan kepada situasi yang berubah-ubah, yang dapat merugikan dirinya (dalam arti jaminan harta debitur atas piutang kreditur). ${ }^{19}$

Berdasarkan uraian di atas terhadap kekuatan mengikat akta notariil perjanjian perkawinan terkait harta bersama yang dibuat pasca pencatatan perkawinaan dapat diketahui yang menjadi ruang lingkup dari pembuatan akta notariil perjanjian perkawinan terkait harta bersama adalah harta benda perkawinan itu sendiri sebagaimana yang diatur dalam Pasal 35, Pasal 36 dan Pasal 37 UU Perkawinan dimana hanya mengenai 2 (dua) jenis harta benda dalam perkawinan yaitu harta bersama adalah harta benda yang diperoleh suami isteri selama perkawinan berlangsung dan harta bawaan adalah harta benda yang diperoleh masing-masing suami isteri sebagai hadiah atau warisan yang dibawa masuk ke dalam perkawinan. Semua harta kekayaaan yang diperoleh selama harta bersama, baik itu secara sendiri-sendiri maupun secara bersama-sama dapat disimpangi dengan dibuatnya perjanjian perkawinan sehingga harta bersama tidak ada lagi di dalam perkawinan suami isteri. Dengan perjanjian perkawinan dapat melindungi hak dan kedudukan suami isteri dari tindakan sewenang-wenang baik oleh suami maupun oleh isteri mengenai harta benda akibat perkawinan.

\subsection{Pencatatan Perkawinan Menurut Undang-Undang Perkawinan Dan Menurut Undang-undang Administrasi Kependudukan}

Berdasarkan Pasal 2 ayat (2) UU Perkawinan bahwa keabsahan sebuah perkawinan selain dilakukan menurut hukum, agama, dan kepercayaannya itu, perkawinan tersebut juga harus segera dilakukan pencatatan pada instansi yang telah ditunjuk berdasarkan undang-undang. Menurut Pasal 1 angka 17 Undang-Undang Nomor 26 Tahun 2006 tentang Administrasi Kependudukan (selanjutnya disebut UU Administrasi Kependudukan), perjanjian perkawinan termasuk kedalam suatu peristiwa penting yang harus dilaporkan ke kantor dinas kependudukan setempat. Begitu pula untuk pencatatan perkawinan antar pemeluk agama yang berbeda diatur dalam Pasal 35 UU Administrasi Kependudukan, pencatatan perkawinan yang tidak dapat dibuktikan dengan akta perkawinan diatur dalam Pasal 36 UU Administrasi Kependudukan menentukan "dalam hal perkawinan yang tidak dapat dibuktikan dengan akta perkawinan,

${ }^{18}$ Wirjono Prodjodikoro, op.cit., hal.121.

${ }^{19}$ J. Satrio II, op.cit., hal. 28. 
pencatatan perkawinan dilakukan setelah adanya penetapan pengadilan" dan pencatatan perkawinan di luar wilayah Republik Indonesia diatur dalam Pasal 37 UU Administrasi Kependudukan. Sebaliknya Perkawinan tidak dicatat adalah perkawinan yang memenuhi Pasal 2 ayat (1) UU Perkawinan tetapi belum dicatatkan sebagaimana dirumuskan dalam Pasal 2 ayat (2) UU Perkawinan.

\section{B AB III \\ PEMBAHASAN}

\subsection{Tata Cara Pembuatan Perjanjian Perkawinan Pasca Pencatatan Perkawinan Secara Notariil}

Secara umum perbuatan hukum pembuatan perjanjian perkawinan yang dilakukan pasca pencatatan perkawinan tidak diatur dalam KUH Perdata maupun UU Perkawinan. Dalam Pasal 29 ayat (1) UU Perkawinan hanya menentukan bahwa perjanjian perkawinan dilakukan "sebelum "atau "pada saat "berlangsungnya perkawinan. Ada beberapa alasan yang dikemukakan oleh suami isteri yang baru membuat perjanjian perkawinan pasca pencatatan perkawinan dimana semua alasan terkait kepentingan dari suami isteri tersebut, diantaranya adanya resiko pekerjaan, kelakuan atau tindakan dari suami atau isteri yang dapat menimbulkan kerugian bagi harta bendanya dan keinginan untuk memiliki tanah dan bangunan di wilayah Indonesia.

Perkembangan masyarakat dewasa ini di perkotaan semakin banyak yang membuat perjanjian perkawinan, terutama bagi pasangan suami isteri yang melangsungkan perkawinan campuran. Hal ini terbukti dengan banyaknya pasangan suami isteri yang mengadakan perjanjian perkawinan selama perkawinan berlangsung terutama dilakukan oleh suami isteri yang melangsungkan perkawinannya secara perkawinan campuran yang berbeda kewarganegaraan.

Prosedur dan tata cara pembuatan perjanjian perkawinan pasca pencatatan perkawinan yang dibuat suami isteri di kantor Notaris adalah pertama suami isteri harus mengajukan surat permohonan yang dibuat secara tertulis dan ditandatangani di atas materai senilai Rp.6.000,kepada Ketua Pengadilan Negeri di daerah suami isteri bertempat tinggal yang isinya mengutarakan alasan-alasan suami isteri untuk mengajukan permohonan perjanjian perkawinan disertai dengan bukti-bukti kelengkapan yang terkait dengan perkawinan dari suami isteri tersebut. Apabila permohonan suami isteri dikabulkan oleh Hakim maka surat permohonan dalam bentuk penetapan keluar sehingga dapat dijadikan dasar untuk membuat perjanjian perkawinan di kantor Notaris secara notariil dan otentik, agar mempunyai kekuatan pembuktian yang kuat karena tercantum di dalamnya waktu saat dibuatnya akta, yaitu pada waktu mana akta itu diresmikan

Kemudian asli surat penetapan pengadilan itu dibawa ke kantor Notaris disertai dengan Kartu Tanda Penduduk (KTP) dan Kartu Keluarga (KK) dari suami isteri. Bagi suami isteri yang berbeda kewarganegaraan harus membawa paspor atau kitas. Pihak Notaris akan meneliti kelengkapan persyaratan yang dibawa oleh calon suami isteri tersebut dan kemudian dicocokkan dengan aslinya. Apabila sudah benar kelengkapan identitas suami isteri maka Notaris akan memanggil suami isteri itu untuk menanyakan mengenai isi dari perjanjian perkawinan yang disepakati untuk dicantumkan dalam draft perjanjian perkawinan.

Apabila draft perjanjian perkawinan yang dibuatkan Notaris telah selesai maka draft tersebut terlebih dahulu diberikan kepada suami isteri tersebut untuk dibaca dan dipahami maksud setiap kalimat dan pasal dalam akta itu. Apabila telah selesai dibaca dan dipahami maka Notaris akan menanyakan kepada suami isteri apakah sudah setuju dengan isi yang terdapat dalam draft yang dibuat Notaris. Kalau draft sudah disetujui maka Notaris akan membacakan akta sesuai hari dan tanggal pada saat itu. Apabila telah selesai dibaca dan tidak ada perubahan lagi maka akta siap ditanda tangani oleh suami isteri untuk kemudian dikeluarkan salinan oleh Notaris.

Kemudian salinan akta perjanjian perkawinan yang telah dibuat di Notaris tersebut harus dicatatkan ke KCS dan kemudian dilaporkan ke kantor dinas kependudukan setempat. Akibat perjanjian perkawinan yang dilakukan pasca pencatatan perkawinan apabila akta perjanjian perkawinannya telah dicatatkan pada pinggir kolom dari akta perkawinan suami isteri dan telah dilaporkan ke kantor dinas kependudukan maka perjanjian perkawinan tersebut berlaku bagi suami dan isteri dan bagi pihak ketiga. Dalam hal perjanjian perkawinan itu belum didaftarkan ke KCS dan belum dilaporkan ke kantor dinas kependudukan maka perjanjian perkawinan itu hanya mengikat suami isteri saja dan tidak mengikat terhadap pihak ketiga sehingga pihak ketiga boleh menganggap suami isteri itu melakukan perkawinan dalam percampuran harta kekayaan. Hal ini dapat dilihat dari penetapan pengadilan negeri sebagai berikut:

a. Penetapan Nomor 269/Pdt.P/2015/PN.Jkt.Tng.

b. Penetapan Nomor 381/Pdt.P/2015/PN.Jkt.Tng.

Pertimbangan suami isteri membuat perjanjian perkawinan pasca pencatatan perkawinan sesuai Penetapan Nomor 269/Pdt.P/2015/PN.Jkt.Tng. adalah berdasarkan asas kebebasan berkontrak, hal ini sesuai dalam Pasal 1338 KUH Perdata disamping itu juga berlandaskan pada ketentuan yang berlaku secara universal bahwa pengadilan negeri dilarang untuk menolak setiap permohonan dan/atau perkara yang masuk. Namun demikian kebebasan membuat perjanjian perkawinan tersebut telah 
diberikan rambu-rambu atau tidak boleh melanggar/bertentangan dengan tata susila (oenden senden), ketertiban umum (operbaar orde) dan tidak boleh bertentangan dengan hukum perkawinan itu sendiri.

\subsection{Bentuk dan Isi Perjanjian Perkawinan secara Notariil}

Pasal 29 ayat (1) menyebutkan bahwa bentuk dari perjanjian perkawinan itu dapat dibuat secara tertulis dihadapan Notaris atau tidak dihadapan Notaris. Hal ini dapat dilihat dari katakata "dapat mengadakan perjanjian tertulis" bisa dimaknai dalam dua pengertian yaitu bahwa perjanjian perkawinan tersebut dibuat dihadapan Notaris, sehingga perjanjian perkawinan itu lebih menjamin kepastian hukum, hal itu dapat dilihat dari setiap pasal-pasal yang ada dalam perjanjian perkawinan itu dan disahkan juga oleh pejabat yang berwenang untuk itu. Sedangkan makna kedua bisa diartikan dibuat secara tertulis hanya diantara pasangan suami isteri itu saja tanpa disaksikan oleh pihak lain sehingga tidak mempunyai nilai kepastian hukum yang begitu mengikat terhadap pihak ketiga karena aktanya dibuat dibawah tangan. Apapun jenis akta perjanjian perkawinan yang dibuat oleh suami isteri, baik itu berbentuk akta notaris maupun akta dibawah tangan, akta-akta itu juga setelah dibuat harus dibawa ke KCS.

Mengenai isi dari perjanjian perkawinan sebagaimana yang diatur dalam UU Perkawinan terdapat pada Pasal 35 yang menyebutkan:

(1) Harta benda yang diperoleh selama perkawinan menjadi harta bersama.

(2) Harta bawaan dari masing-masing suami dan isteri dan harta benda yang diperoleh masing-masing sebagai hadiah atau warisan, adalah dibawah penguasaan masing-masing sepanjang para pihak tidak menentukan lain.

Berdasarkan uraian di atas terhadap kekuatan mengikat akta notariil perjanjian perkawinan terkait harta bersama yang dibuat pasca pencatatan perkawinaan dapat diketahui yang menjadi ruang lingkup dari pembuatan akta notariil perjanjian perkawinan terkait harta bersama adalah harta benda perkawinan itu sendiri sebagaimana yang diatur dalam Pasal 35, Pasal 36 dan Pasal 37 UU Perkawinan dimana hanya mengenai 2 (dua) jenis harta benda dalam perkawinan yaitu harta bersama adalah harta benda yang diperoleh suami isteri selama perkawinan berlangsung dan harta bawaan adalah harta benda yang diperoleh masing-masing suami isteri sebagai hadiah atau warisan yang dibawa masuk ke dalam perkawinan. Dari penjelasan di atas, terhadap isi perjanjian perkawinan meliputi segala hal mengenai harta kekayaan dan utang yang timbul selama perkawinan berlangsung yang mana tidak boleh bertentangan dengan hukum, agama dan kesusilaan.

\section{B AB IV \\ KEKUATAN MENGIKAT AKTA \\ NOTARIIL PERJANJIAN \\ PERKA WINAN PASCA \\ PENCATATAN PERKAWINAN}

\subsection{Kedudukan Akta Notariil Perjanjian Perkawinan Pasca Pencatatan Perkawinan dari jenis-jenis akta}

Apabila perjanjian perkawinan yang dibuat suami isteri pasca pencatatan perkawinan telah dilakukan dalam sebuah akta notariil dan otentik untuk mendapatkan kekuatan bukti secara sempurna maka perjanjian perkawinan tersebut sudah mengikat baik terhadap suami isteri itu sendiri maupun terhadap pihak ketiga yang tersangkut di dalamnya. Olehkarena itu, perjanjian perkawinan harus dibuat dan dituangkan dalam akta notariil dan untuk kemudian dicatatkan pada pinggir kolom akta perkawinan suami isteri di KCS serta perjanjian perkawinan itu selanjutnya dilaporkan ke kantor dinas kependudukan di wilayah mana suami isteri tersebut bertempat tinggal.

Adapun jenis-jenis akta perjanjian perkawinan yang bisa dibuat di kantor Notaris oleh suami isteri dalam perkawinannya adalah:

a. Perjanjian Perkawinan dengan Pisah Harta Sama Sekali

b. Perjanjian Perkawinan dengan Persatuan Untung dan Rugi

c. Perjanjian Perkawinan dengan Persatuan dan pendapatan

Menurut UU Perkawinan, sebuah perjanjian perkawinan dapat mengikat pihak ketiga apabila telah memenuhi ketentuan yang terdapat dalam Pasal 29 ayat (1) yang berbunyi: "Pada waktu atau sebelum perkawinan dilangsungkan, kedua belah pihak atas perjanjian bersama dapat mengadakan perjanjian tertulis yang disahkan oleh pegawai pencatat perkawinan, setelah mana isinya berlaku juga terhadap pihak ketiga sepanjang pihak ketiga tersangkut.'Sedangkan perjanjian perkawinan pasca pencatatan perkawinan yyang dibuat dengan dasar penetapan pengadilan negeri mengacu pada Pasal 1338 KUH Perdata menyebutkan bahwa perjanjian perkawinan yang didasarkan atas kesepakatan dari suami isteri berlaku mengikat layaknya undang-undang bagi suami isteri yang membuatnya. Anggapan tidak tahunya pihak ketiga tentang adanya perjanjian perkawinan hanya dapat diberikan kepada pihak ketiga yang tidak mengetahui bahwa suamiisteri telah membuat perjanjian perkawinan namun belum mendaftarkannya.

Sedangkan pihak ketiga yang mengetahui bahwa suami isteri telah membuat perjanjian perkawinan namun perjanjian perkawinan tersebut belum didaftarkan, maka ia tidak boleh menganggap bahwa perjanjian perkawinan itu tidak ada dan suami isteri melangsungkan perkawinan dengan persatuan harta perkawinan. Jadi apabila perjanjian perkawinan tidak di 
daftarkan sesuai ketentuan dalam peraturan perundang-undangan yang berlaku maka perjanjian perkawinan itu tetap berlaku bagi suamiisteri. Lain halnya jika tersangkut terhadap pihak ketiga, apabila perjanjian perkawinan tidak didaftarkan sebagaimana yang diatur dalam peraturan perundang-undangan yang berlaku maka akibat hukumnya perjanjian perkawinan tersebut tidak mempunyai kekuatan mengikat. Agar perjanjian perkawinan yang dibuat mempunyai kekuatan mengikat terhadap pihak ketiga maka harus dibuatkan secara akta notariil dihadapan Notaris dan selanjutnya disahkan dan dicatatkan ke KCS serta dilaporkan ke dinas kependudukan di daerah tempat tinggal suami isteri yang membuat perjanjian perkawinan tersebut.

\subsection{Analisis Kasus Putusan Pengadilan.}

Pada tanggal 11 Mei tahun 2015 yaitu Tuan Stephan George Winkler dan Isterinya Nyonya Anita Andrita Dewi mengajukan permohonan kepada Pengadilan Negeri Tangerang Jakarta, permohonan tersebut teregister perdata dengan Nomor 269/Pdt.P/2015/PN.TNG. Adapun isi dari permohonan tersebut adalah keduanya memohon kepada Ketua Pengadilan Negeri Tangerang Jakarta untuk memberikan persetujuan berupa penetapan atas perjanjian perkawinan yang akan mereka buat pasca pencatatan perkawinan. Seperti yang telah diketahui suatu perjanjian perkawinan seharusnya dibuat sebelum atau pada saat perkawinan berlangsung sebagaimana yang diatur dalam Pasal 29 ayat (1) UU Perkawinan dan Pasal 147 KUH Perdata. Oleh karena itu agar perjanjian perkawinan mereka dianggap sah maka diperlukan adanya persetujuan dari Hakim.

Para Pemohon melangsungkan perkawinan pada tanggal 12 Pebruari tahun 1999 sebagaimana yang telah ternyata dalam Kutipan Akta Nikah Nomor E1/1999 dan Surat Keterangan Perkawinan yang dicatat dalam Register Akta Perkawinan Nomor: 01/E/LB2005 tanggal 12 Pebruari tahun 2005. Para Pemohon mempunyai penghasilan yang cukup secara ekonomi dan tidak bergantung satu dengan lainnya dan suami juga sebagai kepala keluarga berkewajiban untuk memenuhi kebutuhan hidup keluarga. Sebagaimana diketahui pekerjaan suami yang selalu berpindah dan sering bepergian keluar negeri mengakibatkan mereka merasa perlu mencegah adanya resiko terhadap harta bersama dalam perkawinan mereka sehingga mereka memutuskan untuk membuat perjanjian perkawinan.

Berhubung karena ketidaktahuan mereka akan hukum perkawinan dan kealpaan mereka baru membuat perjanjian perkawinan pasca pencatatan perkawinan selama 17 (tujuh belas) tahun. Untuk mewujudkan perjanjian perkawinan yang dibuat pasca pencatatan perkawinan agar sah diperlukan adanya suatu penetapan dari pengadilan negeri.
Setelah pertimbangan tersebut dibahas maka Hakim mengeluarkan suatu surat keputusan atau diktum hukum yang berisikan butir-butir ketetapan sebagai berikut, yang paling utama adalah Hakim memutuskan untuk mengabulkan permohonan Para Pemohon dan menyatakan sejak tanggal penetapan tersebut telah terjadi pemisahan harta, harta-harta atas nama Pemohon I dan Pemohon II, menyatakan pemisahan harta Pemohon I dan Pemohon II juga terhadap hartaharta lainnya yang akan timbul di kemudian hari tetap terpisah satu dengan lainnya sehingga tidak lagi berstatus harta bersama. Hakim pun memerintahkan Pejabat/Pegawai Kantor Dinas Kependudukan dan Catatan Sipil Propinsi Daerah Khusus Ibukota (DKI) Jakarta untuk mencatatkan pemisahan harta bersama pada catatan pinggir akta perkawinan Para Pemohon dan isi diktum terakhir adalah membebankan biaya permohonan kepada Para Pemohon.

Dalam Penetapan Hakim Nomor: 269/Pdt.P/2015/PN.TNG tersebut yang menjadi hal utama untuk ditinjau adalah hal-hal yang menjadi pertimbangan hukum hakim dalam memberikan putusannya dalam hal mengabulkan permohonan Para Pemohon. Berdasarkan Penetapan Pengadilan Negeri Tangerang Jakarta Nomor: 269/Pdt.P/2015/PN.TNG maka dapat diketahui yang menjadi dasar hukum dan pertimbangan hakim dalam memutuskan permohonan terhadap pembuatan perjanjian perkawinan pasca pencatatan perkawinan adalah adanya kealpaan dan ketidaktahuan Para Pemohon akan aturan hukum mengenai ketentuan perjanjian perkawinan.

Pertimbangan yang digunakan Hakim tersebut kurang tepat dan sudah seharusnya dikaji ulang, karena tidak ada dasar hukumnya. KUH Perdata dan UU Perkawinan itu sendiri adalah hukum, karena berisi kaedah-kaedah hukum untuk melindungi kepentingan manusia. Agar kepentingan manusia dapat terlindungi, maka undang-undang harus diketahui oleh setiap orang, bahkan setiap orang dianggap tahu akan undangundang (iedereen wordt geacht de wet te kennen, nemo ius ignorare consetur). Bahwa setiap orang mengetahui setiap undang-undang ini merupakan asas yang berlaku dewasa ini. ${ }^{20}$

Dalam hal ini seharusnya Para Pemohon sudah mengetahui akan adanya ketentuan mengenai perjanjian perkawinan karena sebagaimana diketahui bahwa semua peraturan perundang-undangan haruslah diumumkan di dalam Lembaran Negara (selanjutnya disebut LN) dengan tujuan untuk diketahui oleh masyarakat umum sehingga peraturan perundang-undangan itu dapat dilaksanakan dan berfungsi untuk melindungi kepentingan hukum dari masyarakat itu sendiri. Berdasarkan uraian di atas, maka alasan yang diberikan Para Pemohon dan

$$
{ }^{20} \text { Sudikno } \text { Mertokusumo, 2003, }
$$
Mengenal Hukum Suatu Pengantar, Yogyakarta: Liberty, hal. 88. 
pertimbangan yang dijadikan dasar oleh Hakim mengenai kealpaan dan ketidaktahuan tentang hukum masih lemah dan kurang tepat sehingga sebagai WNI yang baik. Para Pemohon seharusnya sudah tahu atau berkewajiban untuk mengetahui akan adanya ketentuan mengenai perjanjian perkawinan itu sehingga tidaklah menjadi suatu alasan bagi Para Pemohon bahwasanya mereka tidak mengetahui akan adanya ketentuan perjanjian perkawinan yang dapat mengatur tentang akibat hukum dari harta kekayaan yang ada atau timbul dari perkawinan mereka.

Sebaiknya dalam hal ini, Pemohon I dalam hal ini isteri dapat mengajukan permohonan mengenai perjanjian perkawinan pasca pencatatan perkawinan dengan memakai Pasal $186 \mathrm{KUH}$ Perdata dimana dalam pasal itu disebutkan bahwa seorang isteri dapat meminta pemisahan harta kekayaan bersama terhadap suaminya apabila:

1. Jika suami karena kelakuannya yang nyata telah memboroskan harta kekayaan persatuan dan karenanya itu menghadapkan segenap keluarganya dalam bahaya keruntuhan;

2. Jika karena tidak adanya ketertiban dan cara yang baik dalam mengurus rumah tangga kekayaan suami sendiri, jaminan guna harta kawin si isteri akan menjadi kabur atau jika karena sesuatu kelalaian besar dalam mengurus harta kawin si isteri, kekayaan dapat berada dalam keadaan bahaya. Jelas terlihat bahwa di dalam penetapan, Pemohon I isteri tidak mengajukan salah satu hal sebagaimana tersebut dalam Pasal 186 KUH Perdata di atas sebagai alasan permintaan pemisahan harta bersama pasca pencatatan perkawinan, sedangkan dalam pasal tersebut tertera bahwa hanya 2 (dua) alasan itu yang bisa diterima sebagai dasar diadakannya pemisahan harta bersama pasca pencatatan perkawinan. Jelas terlihat bahwa di dalam penetapan, Pemohon I isteri tidak mengajukan salah satu hal sebagaimana tersebut dalam Pasal 186 KUH Perdata di atas sebagai alasan permintaan pemisahan harta bersama pasca pencatatan perkawinan, sedangkan dalam pasal tersebut tertera bahwa hanya 2 (dua) alasan itu yang bisa diterima sebagai dasar diadakannya pemisahan harta bersama pasca pencatatan perkawinan.

Hal lain yang menjadi perhatian adalah rentang waktu yang cukup lama bagi Pemohon I dan Pemohon II untuk memutuskan membuat perjanjian perkawinan yaitu kurang lebih 17 (tujuh belas tahun) sejak perkawinan mereka berlangsung baru kemudian berkehendak membuat perjanjian perkawinan tersebut. Ada baiknya Hakim dalam putusannya memerintahkan kepada Para Pemohon untuk sebelum membuat dan mendaftarkan perjanjian perkawinan mereka nantinya terlebih dahulu memuat berita tersebut di surat kabar harian untuk beberapa waktu baik ditempat
Para Pemohon suami isteri tersebut bertempat tinggal maupun juga di negara tempat asal Pemohon II karena Pemohon II berkewarganegaraan asing. Hal ini penting dan perlu dilakukan agar nantinya tidak ada pihak manapun yang merasa keberatan dan dirugikan dengan baru dibuatnya perjanjian perkawinan tersebut. Putusan hakim pengadilan adalah sakral dan kuat oleh karena itu dirasa perlu sebelum dikeluarkan telah dilakukan usaha-usaha untuk mencegah adanya tuntutan pihak lain atas putusan tersebut. Pertimbangan hukum hakim lainnya mengenai adanya resiko pekerjaan terhadap harta bersama, adanya penghasilan masing-masing Para Pemohon dan adanya keinginan untuk tetap memiliki hak milik atas tanah ini dikarenakan suami Pemohon I adalah warga negara Jerman dan bukan WNI.

Menurut ketentuan dalam Pasal 21 UUPA yang menyebutkan bahwa hanya WNI yang bisa memegang sertipikat hak milik atas tanah dan apabila yang bersangkutan, setelah memperoleh sertifikat hak milik kemudian menikah dengan WNA, maka dalam jangka waktu 1 (satu) tahun setelah pernikahannya itu tanpa perjanjian perkawinan (percampuran harta), maka WNI tersebut harus melepaskan hak milik atas tanah dalam jangka waktu 1 (satu) tahun setelah pernikahannya itu kepada subyek hukum lain yang berhak dan jika sesudah jangka waktu tersebut lampau, WNI tersebut belum juga melepaskan haknya kepada pihak lain maka hak milik atas tanah hapus karena hukum dan tanahnya jatuh pada negara.

Hal ini jelas menimbulkan kekhawatiran bagi Para Pemohon akan hilangnya kepemilikan dari harta benda perkawinan mereka dikarenakan adanya ketentuan dalam Pasal 21 UUPA tersebut, sehingga untuk menghindari hilangnya hak kepemilikan dari harta benda perkawinan tersebut maka sangat diperlukan adanya pemisahan harta benda perkawinan dari masing-masing dengan membuat perjanjian perkawinan dengan berdasarkan atas penetapan dari pengadilan negeri.

Adanya penetapan pengadilan negeri tersebut menjadi pedoman dan dasar hukum bagi kedua belah pihak suami isteri untuk mengurus dan mengatur harta kekayaan perkawinan mereka karena suatu penetapan pengadilan merupakan produk yudikatif, yang berisi kaedah atau peraturan hukum yang mengikat pihak-pihak yang bersangkutan. Hal ini ditempuh karena pengadilan negeri sebagai instansi hukum yang dijunjung tinggi, dimana produk hukumnya harus dipatuhi oleh siapapun yang terkait di dalamnya.

\section{B AB V PENUTUP}

\subsection{Kesimpulan}

Berdasarkan pemaparan dan pembahasan pada bab-bab di atas maka dapat disimpulkan sebagai berikut: 
1. Ruang lingkup dari pembuatan akta notariil perjanjian perkawinan terkait harta bersama adalah harta benda perkawinan itu sendiri yang terdiri dari 2 (dua) jenis harta benda dalam perkawinan yaitu harta bersama adalah harta benda yang diperoleh suami isteri selama perkawinan berlangsung dan harta bawaan adalah harta benda yang diperoleh masingmasing suami isteri sebagai hadiah atau warisan yang dibawa masuk ke dalam perkawinan. Semua harta kekayaaan yang diperoleh, baik itu secara sendiri-sendiri maupun secara bersama-sama dapat disimpangi dengan dibuatnya perjanjian perkawinan sehingga harta bersama tidak ada lagi di dalam perkawinan suami isteri. Perjanjian perkawinan dapat melindungi hak dan kedudukan suami isteri dari tindakan sewenang-wenang baik oleh suami maupun oleh isteri mengenai harta benda akibat perkawinan.

2. Kekuatan mengikat akta notariil perjanjian perkawinan mengenai harta bersama yang dibuat pasca pencatatan perkawinan terhadap pihak ketiga baru akan berlaku dan berkekuatan hukum apabila perjanjian perkawinan dengan dasar penetapan dari pengadilan negeri itu telah ditindaklanjuti secara tertulis dengan akta notariil dihadapan Notaris dan kemudian dibawa ke KCS untuk dicatatkan dan selanjutnya dilaporkan ke kantor dinas pendudukan di tempat mana suami isteri tersebut bertempat tinggal. Adanya konsensus dari suami isteri untuk membuat perjanjian perkawinan akan menimbulkan kekuatan mengikat sebagaimana layaknya undang-undang (asas pacta sunt servanda).

\subsection{Saran-saran}

1. Disarankan kepada pembuat undang-undang dan pemerintah harus mampu merumuskan susunan kalimat kedalam bahasa hukum peraturan perundang-undangan yang dapat dipahami dengan mudah oleh seluruh masyarakat Indonesia, serta disarankan dapat merevisi atau menambahkan ketentuan yang terdapat dalam Pasal 29 ayat (1) UU Perkawinan, sehingga perjanjian perkawinan yang dibuat pasca pencatatan perkawinan dapat mempunyai dasar dan payung hukum yang kuat serta diterima dan diberlakukan secara nasional.

2. Kepada para Notaris, disarankan agar dapat melakukan suatu terobosan hukum dengan memberikan pelayanan hukum terhadap pasangan suami isteri dalam membuat perjanjian perkawinan pasca perkawinan serta dapat dijadikan masukan bagi pembentukan hukum nasional dibidang hukum perkawinan untuk kepentingan masyarakat dan khususnya dapat dijadikan dasar dalam membuat perjanjian perkawinan di masa yang akan datang.

\section{DAFTAR PUSTAKA}

\section{B uku}

Apeldoorn, L.J. Van, 2004, Pengantar Ilmu Hukum, Cet. XXX, Pradnya Paramita, Jakarta.

Budiono, Herlien, 2010, Kumpulan Tulisan Hukum Perdata di Bidang Kenotariatan Buku Kedua, PT. Citra Aditya Bakti, Bandung.

Djamali, R. Abdoel, 2003, Pengantar Hukum Indonesia, Cetakan ke-8, Raja Grafindo, Jakarta.

Haar, Ter, 1960, Asas-asas dan Susunan Hukum Adat (terjemahan Soebakti Poesponoto K. Ng.), Pradnya Paramita, Jakarta.

Juniasih, Sonny Dewi, 2015, Harta Benda Perkawinan (Kajian Terhadap Kesetaraan Hak dan Kedudukan Suami dan Isteri atas Kepemilikan Harta dalam Perkawinan), PT. Refika Aditama, Bandung.

Mertokusumo, Sudikno, 2005, Mengenal Hukum (Suatu Pengantar), Liberty, Yogyakarta.

Mulyadi, 2008, Hukum Perkawinan Indonesia, Cet. I, Badan Penerbit Universitas Diponegoro, Semarang. Prawirohamidjojo, Soetojo dan Asis Safioedin, 1986, Hukum Orang dan Keluarga, Alumni, Bandung.

Rahardjo, Satjipto, 2006, Ilmu Hukum, PT. Citra Aditya Bakti, Bandung.

Subekti, 2000, Pokok-pokok Hukum Perdata, Intermasa, Jakarta.

Thalib, Sajuti, 1974, Hukum Kekeluargaan Indonesia, Yayasan Penerbit Universitas Indonesia, Jakarta.

\section{Perundang-Undangan}

Burgerlijk Wetboek voor Indonesie (Kitab Undang-Undang Hukum Perdata Staatsblad 1847 Nomor 23), terjemahan R. Subekti dan Tjitrosudibio).

Undang-Undang Nomor 32 Tahun 1954 tentang Penetapan Berlakunya UndangUndang Republik Indonesia tanggal 21 Nopember 1946 Nomor 22 Tahun 1946 tentang Pencatatan Nikah, Talak dan Rujuk di Seluruh Luar Daerah Jawa dan Madura (Lembaran Negara Republik Indonesia Tahun 1954 Nomor 98, Tambahan Lembaran Negara Republik Indonesia Nomor 694). 
Undang-Undang Nomor 5 Tahun 1960 tentang Pokok-pokok Agraria (Lembaran Negara Republik Indonesia Tahun 1960 Nomor 104, Tambahan Lembaran Negara Republik Indonesia Nomor 2043).

Undang-Undang Nomor 1 Tahun 1974 tentang Perkawinan (Lembaran Negara Republik Indonesia Tahun 1974 Nomor 1, Tambahan Lembaran Negara Republik Indonesia Nomor 3019).

Undang-Undang Nomor 23 Tahun 2006 tentang Administrasi Kependudukan (Lembaran Negara Republik Indonesia Tahun 2006 Nomor 124, Tambahan Lembaran Negara Republik Indonesia Nomor 4674).

Undang-Undang Nomor 40 Tahun 2007 tentang Perseroan Terbatas (Lembaran Negara Republik Indonesia Tahun 2007 Nomor 106, Tambahan Lembaran Negara Republik Indonesia Nomor 4756).

Undang-Undang Nomor 2 Tahun 2014 tentang Perubahan Atas Undang-Undang Nomor 30 Tahun 2004 tentang Jabatan Notaris (Lembaran Negara Republik Indonesia Tahun 2014 Nomor 3, Tambahan Lembaran Negara Republik Indonesia Nomor 5491).

Peraturan Pemerintah Nomor 9 Tahun 1975 tentang Pelaksanaan Undang-Undang Nomor 1 Tahun 1974 tentang Perkawinan (Lembaran Negara Republik Indonesia Tahun 1975Nomor 12, Tambahan Lembaran Negara Republik Indonesia Nomor 3050).

\author{
$* * * * *$ \\ Acta Comitas (2017) $1: 26-42$ \\ ISSN : 2502-8960 I e-ISSN : 2502-7573 \\ KEPASTIAN HUKUM HAK KOMUNAL DITINJAU DARI \\ PASAL 16 AYAT (1) h UNDANG-UNDANG NOMOR 5 TAHUN 1960 \\ Ni Ketut Ardani
}

\begin{abstract}
$A B S T R A K$
Kesatuan Masyarakat Hukum Adat ataupun masyarakat yang berada dalam Kawasan tertentu, dalam hal ini masyarakat yang berada dalam kawasan hutan dan perkebunan dapat mengajukan Hak Komunal dengan memenuhi persyaratan yang ditentukan dalam Peraturan Menteri Agraria/Tata Ruang dan Kepala BPN Nomor 10 Tahun 2016. Keberadaan Hak Komunal apabila ditinjau dari UUPA tidak termasuk sebagai salah satu jenis hak atas tanah, khususnya dalam Pasal 16 ayat 1 h UUPA, di mana jenis hak atas tanah dapat dikelompokkan menjadi tiga yaitu Hak atas tanah yang bersifat tetap, Hak atas tanah yang ditetapkan oleh undang-undang yaitu hak atas tanah yang akan hadir kemudian yang akan ditetapkan oleh undang-undang dan Hak atas tanah yang bersifat sementara sebagaimana diatur dalam Pasal 53 UUPA, karena Hak Komunal sendiri ditetapkan berdasarkan Peraturan Menteri Agraria/Tata Ruang dan Kepala BPN Nomor 9 Tahun 2015 yang kemudian dicabut dan dinyatakan tidak berlaku, serta kemudian ditetapkan berdasarkan Peraturan Menteri Agraria/Tata Ruang dan Kepala BPN Nomor 10 Tahun 2016, yang hampir 80 persen isinya sama dengan Permen Nomor 9 Tahun 2015. Kondisi ini dapat menimbulkan keraguan akan diperolehnya kepastian hukum atas kepemilikan Hak Komunal itu sendiri.

Jenis penelitian yang dipergunakan dalam tesis ini dikualifikasikan sebagai penelitian normatif dengan beberapa pendekatan yaitu Pendekatan Perundang-undangan, Pendekatan Konsep), Pendekatan Sejarah dan Pendekatan Perbandingan serta mempergunakan tiga bahan hukum yaitu bahan hukum primer, bahan hukum sekunder dan bahan hukum tersier. Teori-terori yang dipergunakan dalam melakukan analisis adalah Teori Kepastian Hukum, Teori Negara Hukum, Teori Perjenjangan Norma, Teori Fungsional dan Teori Legitimasi dan Validitas serta Teori Kemanfaatan.

Kesimpulan yang diperoleh dari penelitian ini adalah bahwa pengaturan Hak Komunal yang ditetapkan dengan Peraturan Menteri Menteri Agraria/Tata Ruang dan Kepala BPN Nomor 10 Tahun 2016 belum memberikan jaminan kepastian atas Hak Komunal itu sendiri baik dilihat dari dasar penetapannnya maupun dilihat dari beberapa isi pasal-pasalnya.Untuk itu baik Legislatif maupun Pemerintah Pusat perlu menetapkan Hak Komunal itu dalam bentuk undang-undang, sehingga sesuai dengan UUPA sebagai Hukum Pertanahan yang berlaku di Indonesia sehingga dapat memberikan jaminan kepastian hukum bagi pemegang Hak Komunal.
\end{abstract}

Kata Kunci : Kesatuan Masyarakat Hukum Adat, Hak Komunal, Kepastian Hukum. 